\title{
State Financing Impact on Autonomy of Higher Education Institutions and its Link with Economic Activities of Universities
}

\author{
Birute Praneviciene, Aurelija Puraite, Violeta Vasiliauskiene
}

\author{
Mykolo Romerio universitetas \\ V. Putvinskio g. 70, LT-44211 Kaunas, Lithuania \\ E-mail.praneviciene@mruni.eu,aurelija.puraite@gmail.com,v.vasiliauskiene@mruni.eu \\ cross $^{\text {ref }}$ http://dx.doi.org/10.5755/j01.ee.28.5.17899
}

\begin{abstract}
The autonomy of the HEIs and its limits is an object of constant discussions and inquiries. The question that is also researched and accentuated is the relationship between the autonomy of HEIs and the accountability to the society according to certain criteria. The financing aspect of higher education is also one of the most problematic aspects in the system of higher education. None of the models applied for the financing of higher education and measures chosen in Lithuania was able to ensure the accessibility of studies, quality, nor could attract qualified pedagogical personnel. It is stated that insufficient financing of higher education has direct influence on other dimensions of higher education system. If the universities are not granted autonomy, they cannot be innovative and react effectively to social and economic changes, they are not able to correspond to social and economic needs of the state that cannot fulfil expectations of the students to achieve better quality of life. The aim of the paper is to analyse the impact of the financing method of higher education institutions chosen by the state on economic activities of the HEIs and their financial autonomy. In the first part of the paper the trends of the financing of the system of Lithuanian higher education are analysed. The second part of the paper analyses the impact of state financing on institutional autonomy of HEIs. The third part reveals the significance of financial autonomy of HEIs and its impact on the economics of higher education.
\end{abstract}

Keywords: Financing of HE Institutions, Higher Education, Institutional Autonomy.

\section{Introduction}

The problem of the research. The autonomy of higher education institutions (hereinafter - HEI) and its limits is an object of constant discussions and inquiries. The question that is also researched and accentuated is the relationship between the autonomy of HEIs and the accountability to the society according to certain criteria. The move of the university from a service profile to a market profile has caused significant concern and dilemmas for academics and university policy makers (Staskeviciute, Ciutiene, 2008; Asiedu, Nandwa, 2007). The requirements to HEIs are increasing, they are not presumed as being only institutions providing education, but also as business units competing in the field of higher education (Melnikas, 2008; Mets, 2010; Sedziuviene, Vveinhardt, 2009; Snieska, 2008;). There is a significant trend that non-educators increasingly drive plans and targets for education (Murphy, 2005). Only a few authors correctly admit that higher education could not be valued from traditional economic perspectives (Toutkoushian, Paulsen, 2016). The legislator changes the legal regulation quite often and also uses its influence as the main financer of the system of higher education, but randomly questions regarding the financing methods and autonomy of universities and its impact on the economics of the whole higher education are raised. It can be noticed that Baltic states (which for a long time were in the USSR) pay much attention to institutional autonomy, and this is a regular tendency in post-authoritarian states which do not have continuous traditions of higher education. These states have a tendency to regulate meticulously the definitions of various rights but this sometimes has paradoxical effect - if the academic freedom and institutional autonomy are regulated in too much detail they lose their essence. (Thorens, 2006). The dinamics of the legal regulation of Lithuanian law of sciences and education, as well as adopted administrative, financial, procedural measures indicate, that the legislator does not take into consideration the findings of relevant scientific research recently done on the research subject, and the adopted legal regulation does not correspond neither to European practice, nor to scientifically based conclusions. Therefore it is crucial to analyse through scientific approach the politics and legal instruments in the field of education and science, and to provide conclussions and possible ways of improvement of administrative, legal regulation and financial politics on the activities of HEIs.

The relevance of the research. The financing aspect of higher education is one of the most problematic aspects in the system of higher education. It is important to note that the legal regulation of higher education is coordinated with other fields of state regulation - financing, quality assurance (licencing, acreditation, and external evaluation), political activity strategy and development formation. None of the models applied for the financing of higher education and measures chosen in Lithuania was able to ensure the accessibility of studies, quality, nor could attract qualified pedagogical personnel. It is stated that insufficient financing of higher education has direct influence on other dimensions of higher education system. Therefore the scientific analysis of these processes is relevant, important and timely. Some authors state, that universities are becoming so oriented toward the global economy that they no longer address the 
part of their traditional mission that views community and social needs as a major responsibility (Staskeviciute \& Neverauskas, 2008). There is the need to coordinate the extent of state regulatory measures with the principles of institutional autonomy, self-governance and academic freedom. If the universities are not granted autonomy, they cannot be innovative and react effectively to social and economic changes, they are not able to correspond to social and economic needs of the state that cannot fulfil expectation of the students to achieve better quality of life. Funding is not an isolated topic but a set of instruments to achieve the goals of higher education.

The aim of the paper is to analyse the impact of the financing method of higher education institutions chosen by the state on economic activities of the HEIs and their financial autonomy.

Therefore the main tasks of the paper are:

1. To reveal the main means of the distribution of state financing to HEIs, to assess the advantages and disadvantages of those means, to reveal the experience of other countries in financing higher education and in this context to analyse the development of the Lithuanian system of financing of higher education.

2. To evaluate the tendencies in the financing of the Lithuanian higher education system and to detect the flaws of legal regulation in this field, disclose problems of practical implementation, to reveal possible alternatives of the financing of Lithuanian higher education and to propose the measures and mechanisms for implementation.

3. To disclose the correlation between state financing methods, institutional autonomy of HEIs and their possibility to effectively perform economic activities.

The methodology of the research. The article is written in the interdisciplinary area of law and economics, when through the analysis of legal mechanisms the impact of financial regulation of HEIs is revealed on the autonomy of the universities, which is an essential feature of the higher education and may be considered as the guarantee of the fulfilment of the mission of HEIs. The problematic aspects of financing of higher education and institutional autonomy are analysed using the following research methods. The document analysis method allowed gathering, analysing and interpreting written and statistical data, Lithuanian legal acts and other relevant written documents. Analytical - critical method allowed to evaluate the situation of the financing of the higher education and to reveal the problematic aspects and possible solutions. This method was used to formulate generalisations and conclusions. The method of systematic analysis allowed to reveal the disadvantages of the present legal regulation and its influence on the whole system of higher education. The comparative method allowed to compare the financing of higher education in Lithuania and other countries. It should be stated the interdisciplinary character of this paper, which corresponds to a recent wide development of interdisciplinary research methods basically in the field of social sciences (law, economics, sociology, etc.), therefore it is aimed to carry out some "interdisciplinary synthesis" through conclusions of this paper. In order to achieve the above-mentioned goals, the authors will use a variety of methods: from selection and analysis of primary and secondary sources to descriptive, comparative and synthesis methods. Such analysis requires multitudinous, broad and diverse base of empirical data, which could not be collected by authors. Accordingly, the authors will use the data and economic indicators of database of Eurostat, Statistic Department of Lithuania, as well as scientific, operational and theoretical reports related to the issue of migration processes and their determinants (for example, reports of the universities about their financial activities).

\section{The Tendencies of the Financing System of Lithuanian Higher Education}

The financing of higher education system in Lithuania has undergone substantial changes in the two decades of Lithuanian independence. Education policy, whether it is at national or international level, commonly has objectives beyond the area of education, comprising a combination of political, social, economic and pedagogic concerns (Muller, 2011). The models of financing and the methods of state financing for higher education were constantly altered. The search for the system of financing that was optimal and suitable for the needs of society and the state is still underway. The aspiration of the state to regulate higher education may be understood - accessibility of public services, investment into the human capital (education, health, and social security) is considered to be a part of external environment of quality of life, which is usually regulated by means of public policy (Pukeliene \& Starkauskiene, 2011). The last systematic reform of the higher education was carried out in 2009, but it is evident that new demographic and economic tendencies suppose the necessity of a new reform in this specific sector. This is further illustrated by the statements of the newly-elected (in 2016) state officers regarding the inevitability of the reform of science and study institutions. Therefore there are no grounds to state that the system of higher education and its financing system have gained any long-term features. The change in the funding system of the higher education in Lithuania was carried out in several stages, which can be attributed to the adoption of the new versions of the legal acts regulating the activity of higher education institutions. Lithuania is considered as a developing economy, where education levels are as high as, or even higher, than in many developed market economies, even though GDP levels are much lower (Kalyuzhnova \& Kambhampati, 2007). About 70 percent of the graduates of secondary schools every year participate in this activity directly, and their parents, families, educators, the infrastructure personnel of the higher education institution participate indirectly. It can be noted that the number of students is growing from the year 2000. In 2000 there were 96000 students in Lithuania, and in 2008 the number was 144000 (Education [Svietimas]. 2009, 2010). Later this number started decreasing: in the beginning of the academic year of 2015-2016 133000 students were studying in the HEIs, out of them 93524 were studying in universities and 39772 in colleges. To compare with the academic year of 2014-2015, the number of students had decreased by 7000 students, or by 5 percent. 39 percent of the young people aged 20-24 were pursuing higher education (in comparison, in 2014 the number was 40 percent). (Education. [Svietimas] 2015, 2016) The amount of educated people usually indicate the high level of 
life quality in the state (Kilijoniene et al., 2010), therefore there is a great disappointment in the whole system of higher education between the members of the society.

Even though the state funding allocations to the system of education in Lithuania is similar to that in other states (at an average of 4 to 6 percent of GDP), in the year 2009 it even exceeded the EU average and amounted to 6,8 percent of GDP (Ministry of Education and Science of the Republic of Lithuania [LR svietimo ir mokslo ministerija], 2010). However, later the proportion of the GDP allocated to the education system started decreasing due to motives of financial crisis, and in 2012 amounted to 5,8 percent of GDP in Lithuania (Ministry of Education and Science of the Republic of Lithuania [LR svietimo ir mokslo ministerija], 2013). It should be stated that in this case the important factor is not only the amount of the funds allocated but also the principles of their distribution and the effectiveness of their use. Furthermore, it should be noted that the part of the abovementioned assets allocated particularly to higher education (to universities and scientific institutes for all their tasks) comprised 1,3 percent of GDP in the year 2016 (Lithuania's education in numbers [Lietuvos svietimas skaiciais], 2016). This amount corresponds to the tendencies in the EU - European countries spent on average 1,2 percent of GDP on tertiary education (Eurydice, 2001). It should be noted that different sources provide different information regarding financing of the higher education. One of the reasons may be that some institutions consider that financing higher education institutions means only implementing the student's purse doctrine, others include state funding the universities' infrastructure, scientific research etc. This ambiguous situation creates the possibility for various interpretations, therefore it is important to ensure the clarity of the data provided by the governmental institutions and to reveal the contents of the composite parts of financing of higher education institutions.

The appropriations from the state budget still comprise the biggest source of the income of the HEIs but this part is decreasing steadily. From the year 2004 the income of the HEIs from foreign institutions has augmented (almost all these funds come from the EU) (see Table 1). The EU support will decrease from the year 2020, therefore the present higher education system would probably face great shortage of funds. These tendencies formulate a need to review the model of financing of higher education. On the one hand, there is a need for stimulated educational investments, and on the other hand, their efficiency should be evaluated (Giziene \& Vasiliauskaite, 2007).

However, up to date there is no statistical data, what is the real amount allocated by the state to higher education institutions. If we look formally, the input of the public sector comprises the main part of income in the budgets of the HEIs (see Table 1), but it has not been evaluated what part of financing comes back to the state budget by the means of various taxes (income tax, social security tax, health insurance tax, VAT, utilities tax, etc.). For example, Mykolas Romeris University (hereinafter - MRU) expenses in 2015 were 15255100 Eur (income totalled 19853300 Eur), the biggest part of the expense was allocated to the wages of employees (61,2 percent) and social security taxes (18,7 percent). The expenses of Vilnius University (hereinafter - VU) were 150021900 Eur (income 143320200 Eur), the expence allocated to wages of employees comprised 28,97 percent, social security taxes 8,98 percent. The biggest part of the expenses of Siauliai university (55,7 percent) was allocated to the wages of the employees, in the budget appropriations this part is more than 60 percent, and social security tax comprises 16,8 percent of the expenses, utility taxes comprised 6,5 percent, other services - 7,4 percent, and scholarships - 6,2 percent. (Mykolo Romerio universitetas, 2016; 2015 m. Vilniaus universiteto veiklos ataskaita, 2016; Siauliu universiteto veikla 2015 metais, 2016). Similar tendencies may be noticed as well in other universities. Therefore a big part of the income from budget appropriations is returned in one form or another to the state budget.

Other aspect that could be criticized in the budget appropriations - the part of financing according to the results of scientific activity. This form of financing is especially non-transparent; none of the state institutions provide explanations about the validity of the allocation of these funds, effectiveness, and the principles of allocation of these funds between institutions.

The financing situation of higher education in Lithuania is not unique; many EU member states (except for the UK and Ireland) have tendencies that governmental appropriations are still the dominant source of revenues. Their share exceeds two-thirds in all countries, except for the UK. Tuition fees are an important source of revenues only in three countries, i.e. in Italy, Spain and the UK, while in the other countries these fees account for a relatively small share of revenues. The aggregate share of grants and contracts in most of the countries considered range between 10 and 20 percent. Funding is one of the key intervention instruments - for government (ministries, funding councils) as well as university decision-makers (Executive Boards, deans, department heads). In higher education, regulation is related to topics such as standards for the quality of degrees (accreditation), the number of students admitted to public institutions and the freedom of higher education institutions to charge tuition fees and engage in various kinds of other income generating activities (Funding Higher Education: A View Across Europe, 2010). 
Birute Praneviciene, Aurelija Puraite, Violeta Vasiliauskiene. State Financing Impact on Autonomy of Higher Education ...

Table 1

The Structure of the Income of Lithuanian State Universities in 2015

\begin{tabular}{|c|c|c|c|}
\hline $\begin{array}{l}\text { The income of state universities }{ }^{1} \text { in } 2015 \\
\text { University, } \\
\text { Total income, Eur }\end{array}$ & $\begin{array}{l}\text { State budget } \\
\text { appropriations }\end{array}$ & $\begin{array}{l}\text { Income received for } \\
\text { services provided } \\
\text { (proper funds) }\end{array}$ & $\begin{array}{l}\text { Purposive financing (projects, programs, } \\
\text { contracts, etc.) }\end{array}$ \\
\hline $\begin{array}{l}\text { Mykolas Romeris university } \\
19853300 \text { Eur }\end{array}$ & 24,9 percent & 43,2 percent & $\begin{array}{l}31,9 \text { percent (The support from the EU funds } \\
\text { comprises } 27 \text { percent) }\end{array}$ \\
\hline $\begin{array}{l}\text { Vilnius University } \\
143320200 \text { Eur }\end{array}$ & 36 percent & 15 percent & $\begin{array}{l}49 \text { percent (The support from the EU funds } \\
\text { comprises } 45 \text { percent) }\end{array}$ \\
\hline $\begin{array}{l}\text { Vytautas Magnus University } \\
27569600 \text { Eur }\end{array}$ & 44 percent & 22,9 percent & $\begin{array}{l}33,1 \text { percent (the support from the EU funds } \\
\text { comprises } 23,6 \text { percent) }\end{array}$ \\
\hline $\begin{array}{l}\text { Kaunas University of Technology } \\
64059410 \text { Eur }\end{array}$ & 44,3 percent & 23,21 percent & $\begin{array}{l}32,47 \text { percent (the support from the EU funds } \\
\text { comprises } 23 \text { percent) }\end{array}$ \\
\hline $\begin{array}{l}\text { Klaipeda University } \\
20089054 \text { Eur }\end{array}$ & 54,7 percent & 27,67 percent & $\begin{array}{l}17,1 \text { percent (the support from the EU funds is not } \\
\text { indicated) }\end{array}$ \\
\hline $\begin{array}{l}\text { AleksandrasStulginskis University } \\
\text { 23.650,300 Eur }\end{array}$ & 23,3 percent & 24,1 percent & $\begin{array}{l}48,7 \text { percent (the support from the EU funds } \\
\text { comprises } 43,3 \text { percent) }\end{array}$ \\
\hline $\begin{array}{l}\text { Vilnius Art Academy } \\
11153300 \text { Eur }\end{array}$ & 61,76 percent & 11,3 percent & $\begin{array}{l}26,9 \text { percent (the support from the } \mathrm{EU} \text { funds } \\
\text { comprises } 16,3 \text { percent) }\end{array}$ \\
\hline $\begin{array}{l}\text { Siauliai University } \\
9285400 \text { Eur }\end{array}$ & 51,5 percent & 32,9 percent & $\begin{array}{l}15,4 \text { percent (the support from the EU funds is not } \\
\text { indicated) }\end{array}$ \\
\hline $\begin{array}{l}\text { Lithuanian Sports University } \\
7834700 \text { Eur }\end{array}$ & 40,5 percent & 45,8 percent & $\begin{array}{l}13,7 \text { percent (the support from the EU funds is not } \\
\text { indicated) }\end{array}$ \\
\hline $\begin{array}{l}\text { Vilnius Gediminas Technical University } \\
40591000 \text { Eur }\end{array}$ & 51 percent & 25,4 percent & $\begin{array}{l}23,3 \text { percent (the support from the EU funds } \\
\text { comprises } 13,6 \text { percent) }\end{array}$ \\
\hline $\begin{array}{l}\text { Lithuanian University of Educational Sciences } \\
12861590 \text { Eur }\end{array}$ & 54 percent & 29 percent & $\begin{array}{l}17 \text { percent (the support from the EU funds comprises } \\
0,2 \text { percent) }\end{array}$ \\
\hline $\begin{array}{l}\text { Lithuanian Academy of Music and Theatre } \\
6897560 \text { Eur }\end{array}$ & 78,63 percent & 8,93 percent & $\begin{array}{l}12,44 \text { percent (the support from the EU funds } \\
\text { comprises } 7,68 \text { percent) }\end{array}$ \\
\hline
\end{tabular}

Sources: the annual reports of the Rectors of corresponding universities.

The Significance of financial Autonomy of HEIs and its Impact on Economics of Higher Education

One of the most significant composite aspects of the autonomy in higher education is the financial autonomy of the HEIs and its scope. Financial autonomy is composed of such aspects: the means and principles of the allocation of state budget appropriations to the HEIs and their distribution inside the institution, and financial possibilities of the HEIs (related to the legal status of the institutions, to the possibility of the institutions to dispose freely the property assigned to them, the right use the income earned by the institution, to set the tuition fees, the right to borrow money and to invest, the right to set the number of personnel that is necessary and the right to set wages; Mingle, 1983).

Financial autonomy is a field evidently related to other dimensions of higher education, which directly influences other aspects of higher education. For example, the right to set the size of the tuition fees influences the accessibility of higher education. Financial autonomy is a particular field which may indicate a possible dichotomy between the formal and real management autonomy. Even though it could seem that a particular higher school has a high level of autonomy, for example, regarding the administration of buildings, but in reality, its opportunities to sell such property may be very limited by various legal norms or procedures. Therefore the analysis of financial autonomy of universities should also include a detailed analysis of their financial autonomy and its aspects having an influence on the real autonomy of HEIs.

Government funding policies affect both the demand and supply of higher education. For example, the amount of subsidy affects the fees students pay and the demand for higher education places (Harrison, 1997). The method chosen by a particular state to allocate the state budget funds to particular HEIs is considered ashaving the biggest influence to the financial autonomy of a particular institution. Most states gradually accept the method of financing based on long-term contracts between the HEIs and particular ministry, which settles the rights and duties of the HEIs. There are two alternatives for the method of institutional financing (this method is prevailing in Europe and in the OECD member countries) - it is block - grant funding and the line - item budget funding. Financial autonomy is different in both cases.

Financing by block - grant funding is understood as a method where the funds are allocated according to the criteria set out in advance and most often according to the contracts between the ministry and HEI. The funds are designated for several purposes - for the wages of lecturers, for the governance expenses, research. The sum received may be allocated by the university according to their competence and needs, but sometimes some limitation may apply.

The line-item financing method means that the HEIs receive the funds from the state budget that are allocated to different spending needs in advance and they cannot reallocate the funds according to the changed needs. The unused funds must be returned to the state budget at the end of fiscal year. This system was in place in Lithuania before the legal reform in 2009, also in Latvia, Cyprus, Turkey, Serbia, Romania, and Portugal. At the time other universities could keep the funds that were not used, even though the procedures are different in different countries.

\footnotetext{
${ }^{1}$ The data on Lithuanian War Academy and Lithuanian Health Sciencies University is not provided due to the specifics of the financing of those institutions.
} 
In 2009 the line-item financing was in place in Bulgaria, Cyprus, Greece, Latvia, Serbia, Turkey (Estermann, Nokkala, 2009). In 2016 there were three countries left - Cyprus, Greece, Turkey (European University Association, 2017). The universities in other European states receive block-grant financing. The systems in different countries differ according to the level of limitations imposed on the universities regarding the use of funds. The universities of 14 countries may use the funds freely. In 8 countries the institutions are not allowed to move the funds to a different category (it is in place in France, Hungary, Iceland, Latvia, Lithuania, Portugal, Slovakia, Sweden). Even though they cannot dispose of the funds freely, it is acknowledged that their financial autonomy is undoubtedly greater than that of the schools which receive financing according to budget line-item financing model. The widest autonomy of the HEIs exists in the states where the state government almost does not limit the right of the HEIs to distribute the public funds received, but there are only a few states that have such system in place - it is Austria, the Flemish part of Belgium, Estonia, Poland, Switzerland, United Kingdom, Norway, Slovakia.

The funds for the HEIs in Lithuania until the year 2009 were allocated on the basis of contracts concluded between a particular higher education school and the Ministry of Education and Science. The first version of the Law on higher education (2000), Article 54 listed detailed criteria for the allocation of funds. This Article and the principle of the allocation of state funds to the HEIs were being changed several times. There were rules that came into force in 2005 (The Government of the Republic of Lithuania [LR Vyriausybe], 2004) on how to calculate the financial needs of a particular HEI, and there were no rules applicable before. After this amendment came into force, the provision of law specifying the fields that were the basis of the allocation of subsidies by the state was annulled. Therefore the HEIs became directly dependant from the autonomous right of the legislative power to allocate certain funds of state budget. This caused the non-transparent competition between the HEIs, protectionism and other non-democratic phenomena. After the introduction of the abovementioned methodology, confirmed by the government, the funds were allocated according to the methodology in block-grant sum, the universities could allocate the funds for their activities according to the rules of the methodology, where it is stated that a certain amount of funds should be allocated to finance the price of the studies, another part - to maintain infrastructure, to conduct scientific research etc. Therefore it can be concluded that even though it was stated in the legal acts that this financing method is block-grant funding, in reality, it was a mixture of two financing methods (financing by block-grant funding and budget line-item funding).

From the year 2009, a mixed method of financing was introduced. The funds were allocated as basic financing funds (for scientific research, experiential development (social, cultural) and for the development of artistic activity; for administration and infrastructure; for other needs). Other funds were allocated for studies (to cover the price of studies for the students who are financed by the state; to compensate the tuition fees for those students who are self-payers and have reached best study results). Furthermore, the funds were allocated as purposive financing (to implement study programs that were chosen by the means of tender, paying attention to main developmental needs of the state in economic, social and cultural fields).

From 2016 when the new drafting of the Law on Science and Studies was promulgated, the structure of the financing from the budget to the HEIs has changed. The law does not foresee the funds particularly for the purposive financing of the studies. The concept of funds for studies, and in particular the composition of the study price has also changed, and now it includes the household expenses related to the studies as wel. This notion should be considered flawed as it distorts the constitutional principle of equality. This can be illustrated by an example when the same study field (for example, law field) students receive the same student purse funds, even though the institutions carrying out such studies are in an unequal position to compensate the costs incurred taking into consideration specific features of studies. For example, the price for law studies is set the same in Lithuania, and the students ' purses are assigned to all the higher institutions providing law studies. But the price of law studies in Vytautas Magnus university and in the Faculty of Public Security of Mykolas Romeris university is totally different, as the Faculty of Public Security, using the same funds, has to cover not only the wages of the lecturers and other staff employed in the faculty, the price of services and goods, which are related to studies, but also to purchase uniforms for students which are mandatory according to the specifics of studies taught.

The funds for studies are allocated according to the method of student's purse, which, according to the legislator, should encourage competition between the HEIs and the transparent designation of the state budget allocations, as the funds are allocated to a particular student, who chooses a particular HEI and ,brings" the funds to that institution. But there are legal gaps in this kind of regulation (for example, it is not clear how to determine the need for basic financing), which decrease the effectiveness of the reform of higher education. On the other hand, it should be noted that the method of state financing itself is not the sole and not the most important aspect indicating the limits of the financial autonomy of the universities. The concern of any institution with a strong corporate orientation is to meet the demands of the student (consumer) in the most efficient (cost-effective) manner. Adoption of business practices by educational institutions is transforming the educational landscape. As business practices are accepted in education, students have been transformed into consumers, and, in some institutions, programmes are deemed successful only when they drive revenue production or support the acquisition of corporate funding (Natale \& Doran, 2012).

Another important criterion which indicates the degree of financial autonomy of the HEIs is the right for the universities to set the size of the tuition fee themselves. The existence of this right or the limitations to this right means likewise the choice of the financing method of higher education because the HEIs are allowed or forbidden to attract private funds. There are states where this source of income comprises the biggest part of institutions' income and has a strategic influence on the policy on higher education. It is important to note that such tuitions for studies may be named differently and may be set out by different principles and procedural rules. The administrative 
(or registration) fee is also considered as the payments mentioned above. It is usually significantly lower than study tuition.

Data from 2011 shows (Esterman et al., 2011) that in most European states universities may collect study tuitions or registration fees from all or from part of the students. In other countries where higher education is free for the citizens of the state (for example, the Czech Republic, Denmark, Finland, Malta), fees are collected only from international (non-EU) students. Fees are different in different states. For example, in some states fees are collected only for the second stage (Master) studies. In other states fees are collected only for distance / extramural studies, furthermore, in some states fees are collected from the students who are not financed by the state. Even though in the states where education is free there still exists the possibility to tax some students (for example, in the Czech Republic a certain fee is paid by students who did not finish their studies in time). Summarising, it can be noted that in Europe there are three main models for determining and collecting students' tuition - when the size of the fee is determined by the university itself, when the fee is set by the governmental institution centrally, or when it is set by collegial principle (by the agreement between the HEI and a particular state institution).

The first study or registration determination model when the universities may determine the size of their tuition autonomously, existed in 2011 in four European states (Estonia, Latvia, Hungary, Luxembourg). At the same time, the strictest - centralized - method was applied in 6 states France, Austria, Netherlands, Spain, Turkey and Cyprus. The intermediate collegial model was applied in most of European states but there are some variations of this model. In some cases, the state sets the maximum size of the study tuition or registration fee, and the institutions may decide on the exact size of the fee (Lithuania and five other European countries), or the state may sanction the size of the fees set by the university. It can be noted that very often the states apply a mixed collegial model where, for example, the states regulate the size of the fees for the students from the state and other EU countries, but the fee for the third country citizens may be set by the universities themselves.

Even though the foreign experts noted in their report of 2009 that Lithuania is a state where the autonomy is conditionally ensured as to the size of the student's tuition (as the institutions may, after negotiations with the state, fix the size of the tuition), the development of this notion indicates that Lithuanian universities had limited discretion for a long time to set the size of the tuitions. For example, in 2001 Article 59 of the Law on higher education set a fixed fee for all students who are not financed by the state.

This norm with some non-essential amendments was in force until 2009. Therefore it can be concluded that such legal regulation had abolished the financial autonomy of the HEI. In 2009 after the new Law on Science and Studies was adopted the procedure of the determination of the size of study tuition was changed and the full autonomy of the HEIs was established: „The price of studies is determined by the HEI" (Law on Science and Studies, the wording of the version of Law of 30 April 2009, Article 76, part 1). The criteria for determining the price of studies were set by the legal rules. If the student gets in the place financed by the state, the state pays the institution the normative price of studies for that student. Therefore we can see a certain indirect influence on the HEIs, but it is evident that such legal regulation establishing the right for the institution to set the size of the tuition, increases the general degree of the financial autonomy. It is worthwhile mentioning, that there are no variety of possibilities for the business sector to involve into the financing schemes of higher education in Lithuania, for example, there are no legal provisions or benefits to the employer willing to provide financial aid to the student (comparing with models in other states, such as USA, where employer provides educational assistance and requires the student to work during the time they receive educational assistance; Walker, Florea, 2014).

Another important criterion that indicates the scope of the financial autonomy of the universities is the right of the universities to borrow funds and to invest. It can be noted that the universities have the right to borrow funds in many states but only in several states they are allowed to carry out investment activities (for example, invest in shares, issue bonds etc.). According to the data from the year 2011, in twothirds of the European states legal norms determined the right of the universities to borrow money, but most of the time those rules indicated also some limitations to such right (for example, requirement of an advance consent of state institutions, limitation on the maximum size of the credit, fixing a list of aims which could be the grounds for borrowing etc., this is in place in Latvia, Denmark, for example). In some states, it is allowed to borrow only from the national bank, like in Sweden. In one-third of the European states according to 2009 data (in Greece, Hungary, Portugal, Switzerland, Turkey, Norway) the HEIs did not have the right to borrow money, but in some states (Switzerland, Greece) the universities may establish other legal entities (funds, centres) which then may borrow from private subjects.

Until 2009 the HEIs could not borrow funds or carry out any other financial activity in Lithuania. All versions of the Law on higher education indicated that "the property of the HEIs includes the buildings owned and other tangibles, nonbudget financial resources, securities, intellectual property (as far as it does not infringe authors' rights) and other property obtained by lawful means" (Article 11 (1)). It could be stated that according to this wording the universities could have securities, and that would mean the right to invest in them or the right to establish other legal entities. But in fact the other explanation is more plausible - that this notion in the Law was more related to the right to inherit securities (but the owner of such securities would be the state, as the legal form of the HEIs was budgetary institution and all property obtained by budgetary institution belonged to the owner of the budgetary institution - that means, to the state), and the right to establish other legal entities could be attributed only to private, non-governmental HEIs.

But from the year 2009, after the reform of higher education, the HEIs obtained autonomy as well in the field of borrowing and in other fields of financial activity. The model chosen was more liberal and democratic, it allowed HEIs to borrow funds, but this ability was limited by certain notions. The right of the HEIs to establish new legal entities is likewise limited. It can be noted that the version of 2009 of the Law on Science and Studies also defined a new field of activity of the universities which was not regulated 
previously and which also comprises some property rights it is intellectual activity and the right to intellectual property. The law sets out clearly the property right to property authors', nwhich emerge from intellectual activity (science or artistic production and industrial property objects, other intellectual property objects), obtained by contracts or as indicated by law (Law on Science and Studies, Article 82).

One of the most significant factors influencing the financial autonomy of the HEIs is the extent of the universities' right to use their long-term property. The right of the universities to buy, sell, build, mortgage the buildings and estates they possess is a very important guarantee of their financial autonomy. But it is important to note that this particular field is the field of autonomy most influenced by traditions, cultural conscience and relativism. It is particularly evident in European states where the historic traditions of the higher education are very long and the universities are located in buildings having historical and cultural value. There are two main management models of the immovable property - when the universities manage, use and dispose of the immovable property fully, and, secondly, when the state rents or allows to use gratuitously the property for HEIs retaining the ownership (even though it is not prohibited for them to obtain or build new immovable property of their own ownership). There are some states (Finland, Germany, Sweden, and Austria) where the property entrusted to universities is owned by specialized institutions of the state (Financially sustainable universities, 2008). It can also be noted that in the states where the universities own immovable propertythey are not totally free to dispose of this property without any limits. Usually, HEIs have to get the consent of a particular institution (in Norway), or it is forbidden to sell such property (in Greece).

The right of the HEIs to freely dispose of the immovable property was the most discussed problem from 1990 in Lithuania. In theWorld Bank report of 2007 it is noted that in Lithuania the autonomy of the universities is mostly limited by the limitations to use property, the determination of study tuitions by state and the prohibition to borrow funds (Canning, Godfrey, Holzer-Zelazewska, 2007). The rights of state science and study institutions to manage, use and dispose of their property were regulated until 2009 by the Law on science and study, Law on higher education and Law on the Management, use and disposition of the state and municipal property. The existing regulation set many limitations on the state science and study institutions in the field of use of the property and they could not react more flexibly to the changes in the market when implementing the aims set for them by the state. On the one hand, the regulation foresaw the right for the state science and study institutions to manage, to use and to dispose of the property that they have earned by the right of ownership, but on the other hand, the same legal norms foresaw as well big limitations in passing decisions regarding property management, usage and disposition.

The origins of the problem lie in the legal status of the HEIs. From the restoration of independence of Lithuania in 1990 until the year 2009 the HEIs were established as budgetary institutions. According to the Law on budgetary institutions of 1995, which was the basis for the activity of all state higher education institutions, ,a budgetary institution is the institution of a state or municipality, which is established according to the law, fully or partially financed from the budget and so named in the establishment act or in its statute"(Article 2). The budgetary institutions are established by state authorities, and it means that their property is considered as state property. For a long time there were discussions regarding the change of the status of the HEIs from budgetary institutions to public institutions, accordingly the Law on budgetary institutions was also changed (Article 13: „Budgetary institution may not be reorganized into any other legal entity, except for the cases indicated by law"), adding the notion that this norm does not apply for the state higher education schools until 31 December 2011. The reform was fulfilled when the new draft of the Law on Science and Studies in 2009 was adopted, which stated that ,state higher school is public legal entity acting as a public institution, having the autonomy guaranteed by the Constitution of the Republic of Lithuania, and special status guaranteed by this and other legal acts. The non-state higher school is a public legal entity, acting as a public institution, or private legal entity“ (Article 6(4)). The Law on public institutions is applied to the HEIs so far as it does not contradict the Law on Science and Studies, therefore it can be stated that the HEIs have a status of special public institutions.

After the reform of the higher education system in 2009, some changes were implemented as well in the property management field. Firstly, it can be noted that for the first time legal acts indicated not only the specific rules on the management of the property, but also the principles for the management and disposition of property, such as the principles of public benefit, effectiveness, rationality, accountability, autonomy of economic activity (Law on Science and Studies, Article 79, version of 2009). The law also establishes full inviolability of the higher schools regarding their buildings and territories. The change of the territory of the HEI or the managers of the state buildings may be affected only by the Government after taking into account the opinion of the university council. If the council of the state university does not agree with the change, the territory limits or the managers of the buildings may be changed only by Seimas (Law on Science and Studies, Article 86 (2), resit of 29 June 2016).

There are two legal regimes of the property: 1) assets, managed in trust; 2) assets, managed by the ownership State's higher schools are entrusted in trust rights with the long-term tangible assets owned by the state. The conditions of the trust are set out in the Law on the Management, use and disposition of the state and municipal property. The assets managed in ownership are the assets invested by the state; the income from the tuitions, income from economic activity, scientific activity and the services provided; funds and other assets which were received as aid according to the Law on charity and support; other financial assets, except for the funds from state budget; assets purchased by using state budget funds, except for the immovable property purchased by using the European Union funds; funds from state budget and state foundations; gifts; inherited property; property rights from intellectual activity; income, property or other benefits obtained by managing and using funds or other property, or from the disposing of them. 
There are more limitations foreseen in the legal acts on the assets managed by HEIs in trust, than on the assets managed by ownership. The assets passed on to the higher school on the basis of trust contract can be rented to third persons, given to third persons to use on grounds of loan for use, if it was foreseen in the trust contract and if it is necessary to ensure the functions of the HEI. The assets managed by trust may not be an object of exaction for the obligations of the state higher school, including obligations arising from the management, use or disposition of this asset (29 June 2016 version of Law on Science and Studies, Articles 87(5) and 87(6)). These assets are managed according to the Law on the Management, use and disposition of the state and municipal property, which indicates that the HEIs may not give these assets into the ownership of other persons, to put mortgage on it or otherwise restrict it in order to guarantee its own or other person's obligations, to rent it, to loan it for the use, or to give it to other persons to use in any other way.

On the other hand, the assets managed by ownership may be disposed of more liberally. The HEIs may conclude such contracts which do not contradict their statutes and main aims. But even in this case there are limitations on the right of disposition of the owned assets. The institutions of higher education have to conform to the methodology specifying determination of the price of the assets, furthermore, an advance consent from the Government or institution that were authorized by Government is necessary. Quite a few European states allow their HEIs to dispose of their assets without any additional limitations, for example, Austria, the Czech Republic, Denmark, Spain, Netherlands, Slovakia, and Italy (University autonomy in Europe, 2017).

Therefore it can be concluded that the HEIs in Lithuania have not acquired full autonomy in the assets management after the reform of higher education in 2009, but the present changes ensure a greater autonomy of the universities. It can also be stressed that there were discussions in the public space regarding the whole reform of higher education and regarding the property management as well. Some authors have expressed their concerns that in case the HEIs were allowed to dispose of their assets freely, it could be transferred to the third persons thus infringing the main principles of higher education. But, as the practice shows, the state acting as the establisher of HEI and transferring the assets to the HEI is prone to pass ownership rights on movable property, whereas the immovable property is usually transferred on trust rights. Therefore it can be concluded that the Law on Science and Studies foresees sufficient safeguards to protect the interests of state and society.

\section{Conclusions}

1. Analysis of the impact of financing method of higher education institutions chosen by the state on economic activities of the HEIs and their financial autonomy showed, that the state can use financing methods to control HEIs' activities, as the steted is alleged to be the main finanace source of HEIs. The research disclosed that the modern higher education institutions receive almost part of their income from other sources, and there are no data evaluating what is the part of funding that comes back to the state budget by the means of various taxes.

2. A particular model of financing higher education and state financing method depends on the political interests and state strategy, the knowledge of economic theories and influence on public opinion. In any case the chosen directions of financing have to conform to world tendencies having influence on the whole system of higher education: diversification of financial sources, attracting private and business funds; the creation of the system allowing to use state appropriations effectively; the increase in the financial autonomy of higher education. The increase in the appropriations only from the state budged cannot solve financing problems of higher education, because the possibilities of state budget are limited. Therefore it is important that universities would search for other means of financing themselves.

3. Higher education is becoming more en masse, commercialized and industrialized, as the market and society needs have an increasing influence on the financing of the studies, to the creation of study programs, to the control of study quality. This created a paradox situation when the sate, on one hand, by the means of legal rules, gives a rather wide institutional autonomy to HEIs, which enables them to make decisions on the inner management of the HEI. On the other hand, other state regulation measures (state financing, accreditations, and other procedures of evaluation of the results of activity of HEIs) have a direct impact on the activity of HEIs. The tendency is that other means of state regulation have the same if not bigger influence than the legal regulation, and the soundness of the use of such measures and state control is more difficult as the choice of such state regulation measures is often made not according to legal arguments, but according to economic, political and other indirect arguments.

4. The main aspects that can be highlighted regarding the relationship between the state regulation and institutional autonomy of HEIs are the legal status of the institution of higher education and constitutional protection level, the independence of the managing and deciding organs, degree of financial and academic freedom. In Lithuania the HEIs have the autonomy on the size of tuitions, assets' management, borrowing and other financial fields. However, the possibility to borrow funds is limited by certain legal regulations compulsory to the HEIs as well, furthermore, the assets managed by ownership may be managed by the HEIs only by taking into account the state position on certain questions, for example, the immovable property may be transferred to third persons only with consent of the Government or authorised institution. The HEIs did not gain full autonomy in the field of assets management even after the reform of higher education, but it can be stated that the present changes ensure a greater autonomy of the universities. 


\section{References}

Activity of Lithuanian sports university in 2015. [Lietuvos sporto universiteto veikla 2015 metais] (2016). Retrieved from http://www.lsu.lt/sites/default/files/dokuumentai/Rektoriaus\%20ataskaita_Internetui.pdf.

Asiedu, E., \& Nandwa, B. (2007). On the Impact of Foreign Aid in Education on Growth: How Relevant Is the Heterogeneity of Aid Flows and the Heterogeneity of Aid Recipients? Review of World Economics, 143 (4), 631-649. Doi: 10.1007/s10290-007-0125-9

Berdahl, R. (1990). Academic freedom, autonomy and accountability in British universities. Studies in Higher Education, 15 (2), 69-80. http://dx.doi.org/10.1080/03075079012331377491.

Canning, M., Godfrey, M., \& Holzer-Zelazewska, D. (2007) Higher Education Financing in the New EU Member States. Leveling the Playing Field. World Bank Working Paper No. 112. Washington: World Bank.

Decree of the Government of the Republic of Lithuania Regarding the approval of the methodology of determination and allocation of state budget needs of the Republic of Lithuania for higher education and research institutions [Del Lietuvos Respublikos valstybes biudzeto lesu poreikio nustatymo ir ju skyrimo mokslo ir studiju institucijoms metodikos patvirtinimo]. (2004) (Official Gazette [Valstybes zinios], 2004, Nr. 151-5493). Retrieved from www.tar.lt

Education [Svietimas]. 2009. (2010). Vilnius: Department of statistics.

Education. [Svietimas]. 2015. (2016). Vilnius: Department of statistics.

Estermann, T., Nokkala, T., \& Steinel, M. (2011). University Autonomy in Europe II. The Scorecard. European University Association.

Estremann, T., \& Nokkala, T. (2009). University Autonomy in Europe I. Brussels: European University Association.

European University Association. (2017) University Autonomy in Europe. Retrieved from http://www.universityautonomy.eu/dimensions/financial/

Eurydice. (2001). Modernisation of Higher Education in Europe: Funding and Social Dimension. Education, Audiovisual and Culture Executive Agency.

Financially Sustainable Universities: Towards full costing in European universities. (2008). Brussels: European University Association.

Giziene, V., \& Vasiliauskaite, A. (2007). Evaluation Models of Investments to Education: Application Peculiarities. Inzinerine Ekonomika-Engineering Economics(2), 50-58. Retrieved from http://inzeko.ktu.lt/index.php/ EE/article/view/11474/6188

Harrison, M. (1997). Government Financing of Higher Education in Australia: Rationale and Performance. Australian Economic Review. 30 (2), 225-39. 10.1111/1467-8462.00022

Kalyuzhnova, Y., \& Kambhampati, U. Education or Employment-Choices Facing Young People in Kazakhstan. Journal of International Development, 19, 607-626. Doi: 10.1002/jid.1343

Karran, T. (2007). Academic Freedom in Europe: A Preliminary Comparative Analysis. Higher Education Policy, 20, 289313. doi:10.1057/palgrave.hep.8300159

Kilijoniene, A., Simanaviciene, Z., \& Simanavicius, A. (2010). The Evaluation of Social and Economic Development of the Region. Inzinerine Ekonomika-Engineering Economics, 21(1), 68-79. Retrieved from http://internet.ktu.lt/lt/ mokslas/zurnalai/inzeko/66/1392-2758-2010-21-1-68.pdf.

Law on budgetary institutions (1995) [Biudzetiniu istaigu istatymas]. (Official Gazette [Valstybes zinios], 1995, Nr. 1042322). Retrieved from www.tar.lt.

Law on higher education [Aukstojo mokslo istatymas]. (Official Gazette [Valstybes zinios], 2000, Nr. 27-715). Retrieved from www.tar.lt

Law on public institutions (2009). [Viesuju istaigu istatymas]. (Official Gazette [Valstybes zinios], 2009, Nr. 54-2141). Retrieved from www.tar.lt.

Law on Science and Studies [Mokslo ir studiju istatymas]. (Official Gazette [Valstybes zinios], 2009, Nr. 54-2140). Retrieved from www.tar.lt

Law on the Management, use and disposition of the state and municipal property (1998). [Valstybes ir savivaldybiu turto valdymo, naudojimo ir disponavimo juo istatymas]. (Official Gazette [Valstybes zinios], 1998, Nr. 54-1492). Retrieved from www.tar.lt.

Lithuanian Academy of Music and Theatre. Year 2015. The annual activity report [Lietuvos muzikos ir teatro akademija. 2015 metai. Metine veiklos ataskaita]. Retrieved from lmta.lt/get.php?item=f\&id=20560.

Lithuania's education in numbers [Lietuvos svietimas skaiciais]. 2016. Studies [Studijos]. (2016) Vilnius: The Ministry of Education and Science of the Republic of Lithuania [Lietuvos Respublikos Svietimo ir mokslo ministerija]. 
Birute Praneviciene, Aurelija Puraite, Violeta Vasiliauskiene. State Financing Impact on Autonomy of Higher Education ...

Melnikas, B. (2008). Integration Processes in the Baltic Region: the New Form of Regional Transformations in the European Union. Inzinerine Ekonomika-Engineering Economics(5), 54-64. Retrieved from http://www.inzeko.ktu.lt/index.ph $\mathrm{p} / \mathrm{EE} / \mathrm{article} / \mathrm{view} / 11583$

Menand, L. (1996). The Limits of Academic Freedom. In Menand, L. (ed.) The Future of Academic Freedom. (pp. 3-20). Chicago: University of Chicago Press.

Mets, T. (2010). Entrepreneurial Business Model for Classical Research University. Inzinerine Ekonomika-Engineering Economics, 21(1), 80-89. Retrieved from http://internet.ktu.lt/lt/mokslas/zurnalai/inzeko/66/1392-2758-2010-21-180.pdf.

Mingle, J. R. (ed.). (1983). Management Flexibility and State Regulation in Higher Education. Atlanta: SREB.

Muller, T. R. (2011). Introduction to Human Resource Development Versus the Right to Education: Reflections on the Paradoxes of Education Policy Making. Journal of International Development, 23, 253-261. DOI: 10.1002/jid.1768

Murphy, P. (2005). Education, Educators and Financing Modalities: Reflections on Experience in Uganda. Journal of International Development. 17, 131-147. Doi: 10.1002/jid.1181

Mykolas Romeris university. The Report of the Rector. [Mykolo Romerio universitetas. Rektoriaus ataskaita]. 2015. (2016). Retrieved from https://issuu.com/mruni_issuu/docs/mru_rektoriaus_ataskaita_2015.

Natale, S. M., \& Doran, C. (2012). Marketization of Education: An Ethical Dilemma. Journal of Business Ethics, 105, 187196. Doi 10.1007/s10551-011-0958-y

Pukeliene, V., \& Starkauskiene, V. (2011) Quality of Life: Factors Determining its Measurement Complexity. Inzinerine Ekonomika-Engineering Economics, 22(2), 147-156. http://dx.doi.org/10.5755/j01.ee.22.2.311

Report of activity of Vytautas the Great university in 2015 [Vytauto Didziojo universiteto 2015 metu veiklos ataskaita]. (2016) Retrieved from http://www.vdu.lt/wp-content/uploads/2016/04/2015\%20m.\%20VDU\%20veiklos\%20 ataskaita(pilna).pdf

Report of activity of Klaipeda's university [Klaipedos universiteto veiklos ataskaita]. 2015 (2016). Retrieved from http://www.ku.lt/wp-content/uploads/2016/02/20160323_9N_72_-KU-2015-m.-veiklos-ataskaita.pdf

Report of activity of Lithuanian university of educational sciences in the year 2015 [Lietuvos edukologijos universiteto 2015 metu veiklos ataskaita] (2016). Retrieved from https://leu.lt/download/38203/universiteto\%20ataskaita\%202015.pdf.

Report of Aleksandas' Stulginskis' university activity in 2015 [ Aleksandro Stulginskio universiteto 2015 metu veiklos ataskaita] (2016). Retrieved from http://asu.lt/wp-content/uploads/2014/09/ASU-2015-veiklos-ataskaita_.pdf.

Report of Vilnius' university activity in 2015 [2015 m. Vilniaus universiteto veiklos ataskaita] (2016). Retrieved from http://www.vu.lt/site_files/Senatas_Taryba/T-2016-Vilniaus_universiteto_2015_m._veiklos_ataskaita.pdf

Snieska, A. (2008). Research into International Competitiveness in 2000-2008. Inzinerine Ekonomika-Engineering Economics(4), 29-41. Retrieved from http://www.inzeko.ktu.lt/index.php/EE/article/view/11560

Staskeviciute, I., \& Ciutiene, R. (2008). Processes of University Organizational Intelligence: Empirical Research. Engineering Economics(5), 65-71. Retrieved from http://inzeko.ktu.lt/index.php/EE/article/view/11587/6271.

Staskeviciute, I., \& Neverauskas, B. (2008). The Intelligent University's Conceptual Model. Inzinerine EkonomikaEngineering Economics(4), 53-58. Retrieved from http://inzeko.ktu.lt/index.php/EE/article/view/11563/6244

Sedziuviene, N., \& Vveinhardt, J. (2009). The Paradigm of Knowledge Management in Higher Educational Institutions. Inzinerine Ekonomika-Engineering Economics(5), 79-90. Retrieved from http://internet.ktu.lt/lt/mokslas/zurnalai/ inzeko/65/1392-2758-2009-5-65-079.pdf

The activity of Siauliai university in 2015 [Siauliu universiteto veikla 2015 metais] (2016). Retrieved from http://www.su.lt/images/Universitetas/Dokumentai/SU_VEIKLA_2015.pdf

The annual report of activity of Kaunas' university of technology [Kauno technologijos universiteto metine veiklos ataskaita]. 2015 (2016). Retrieved from http://ktu.edu/sites/default/files/ktu_ataskaita_2015_leidinys_faktai_ir_ skaiciai_uz_2015_m.pdf.

The Ministry of Education and Science of the Republic of Lithuania [LR svietimo ir mokslo ministerija] (2013). The funding of education: how many, to whom and how [Svietimo finansavimas: kiek, kam ir kaip]. The analysis of the problem of education [Svietimo problemos analize]. 13 (99).

The Ministry of Education and Science of the Republic of Lithuania [LR svietimo ir mokslo ministerija], (2010). Lithuania's education. Only facts. Annual report 2010 [Lietuvos Svietimas. Tik faktai. Metinis pranesimas 2010]. Vilnius: the cente of education supply. 
The report of annual activity of Vilnius' art academy [Vilniaus dailes akademijos metines veiklos ataskaita] 2015 (2016). Retrieved from http://www.vda.lt/uploads/documents/files/VDA\%20dokumentai/_2015_metine_VDA_ataskaita_ maketas_siuntimui.pdf.

Thorens, J. (2006). Liberties, Freedom and Autonomy: A Few Reflections on Academia's Estate. Higher Education Policy, 19 (1), 87-110. https://doi.org/10.1057/palgrave.hep.8300111

Toutkoushian, R. K., \& Paulsen, M. B. (2016) Economics of Higher Education. Background, Concepts, and Applications. Netherlands: Springer. https://doi.org/10.1007/978-94-017-7506-9

Turner, J. (1988). The Price of Freedom. In Tight, M. (ed.) Academic Freedom and Responsibility. (pp. 104-113). Buckingham: SRHE/OU Press.

Vilnius Gediminas' technical university [Vilniaus Gedimino technikos universitetas]. 2015 (2016). Retrieved from http://www.vgtu.lt/uploads/files/dir1081/dir54/dir2/17_0.php.

Walker, R. L., \& Florea, L. (2014) Easy-Come-Easy-Go: Moral Hazard in the Context of Return to Education. Journal of Business Ethics, 120, 201-217. Doi 10.1007/s10551-013-1656-8

The article has been reviewed.

Received in April, 2017; accepted in December, 2017. 